\title{
MANTLE XENOLITHS FROM ALKALI BASALTS IN THE NOGRAD-GOMOR REGION OF HUNGARY AND CZECHOSLOVAKIA.
}

\author{
Szabó, ${ }^{(1),}{ }^{(2)}$ Csaba and Taylor, ${ }^{(1)}$ Lawrence $A$.
}

(1) Dept. of Geological Sci., Univ. of Tennessee, Knoxville, TN 37996 USA; (2) Dept. of Petrol. \& Geochem., Eotvos Lorand University, Budapest, Hungary.

INTRODUCTION: Neogene to Quaternary alkali basalts are widely distributed within the Carpathian-Pannonian region of eastern Europe. These basalts contain abundant ultramafic and mafic nodules, as well as a large variety of mafic and salic megacrysts. The present study focuses on the great variety of ultramafic xenoliths from the Nograd-Gomor Region (NGR). We have collected more than 100 ultramafic xenoliths from 4 of the most important localities in the NGR (Fig. 1), and 43 samples were selected for detailed study. These have been studied in thin section, and numerous electron microprobe analyses have been performed on the various phases. These petrographic and chemical data form the basis for characterization of these xenoliths and provide insight into their petrogenetic evolution and metasomatic histories. Trace element and isotopic studies are in progress.

GEOLOGIC SETTING: In the NGR, numerous volcanic vents have produced extensive flows and dikes and thereby formed a wide plateau. Volcanic activity started at $2.8 \mathrm{Ma}$ and continued to $1.0 \mathrm{Ma}$ (Balogh et al., 1986). The early stage of development of the Pannonian Basin involved upwelling of a mantle diapir (Stegena et a1, 1975; Adam, 1976). This is thought to have initiated the thermal regime from which the volcanic rocks were later derived.

Host Rocks - The NGR basalts range in texture from aphanitic to porphyritic. Mainly olivine, but also clinopyroxene, and plagioclase, occur as phenocrysts wịthin a groundmass of clinopyroxene, plagioclase, apatite, oxide phases, - glass, - nepheline, Irace amounts of $\mathrm{K}$-feldspar and phlogopite. The basalts possess low silica contents $(46.6-49.7 \%)$, high alumina (16.3$18.6 \%)$, high total alkalis $(5.9-7.2 \%)$, and low $\mathrm{Mg}$ 非 (53.3-65.7). When compared to typical xenolith-bearing alkali basalts from other world-wide locales, they are notably lower in $\underline{\text { Mg }}$ 作 basalts $(67-74)$. This factor, in addition to their high differentiation indices $(39-51)$ and high normative nepheline contents (up to $10.7 \%$ ), may indicate that the original magma was modified by fractional crystallization and assimilation at depth.

Xenoliths - The xenoliths from NGR can be divided into three texturally and genetically distinct groups: 1) Cr-Diopside Suite (cf, Wilshire and Shervais 1975); 2) Clinopyroxenite and Gabboic Series, which may be representative of cumulates of the Al-augite suite of Wilshire and Shervais (1975); and 3) accidental upper crustal xenoliths. 


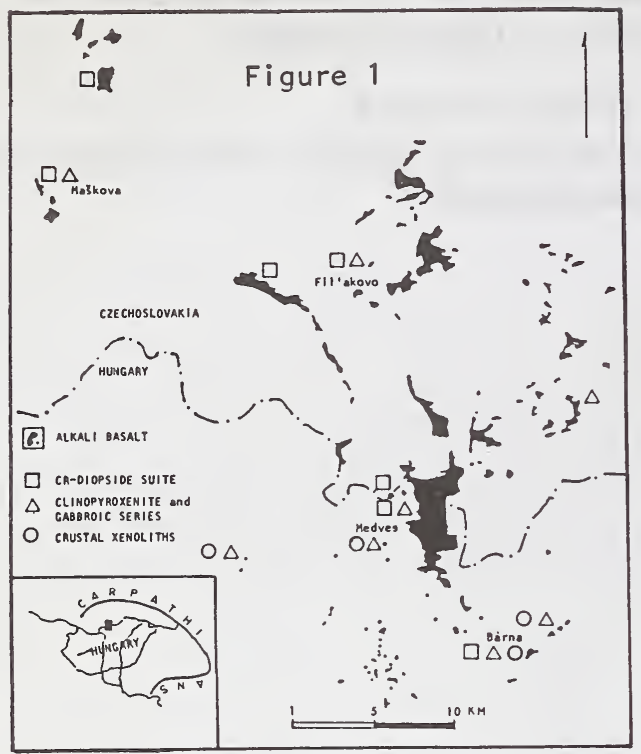

XENOLITH PETROGRAPHY AND CHEMISTRY:

The xenoliths which are the object of this present study are from the $\mathbf{C r}-$ Diopside Suite. These xenoliths have been grouped on the basis of mineralogy and texture into three types:

1) Spinel Lherzolites and Harzburgites - These are modally dominated by olivine with small amounts of amphibole locally present. Most of the lherzolites, which now appear to be "dry", possess sites where a hydrous phase was present but is now occupied by a secondary assemblage consisting of clinopyroxene, spinel, feldspar, phlogopite, amphibole, olivine, and glass. The over-all texture of this type of xenolith is classified (after Mercier \& Nicolas, 1975) as porphyroclastic and equigranular, with some transitional.

2) Dunite and Wehrlite - Olivine makes up 85 to 90 modal \% of these xenoliths. Phlogopite with distinct

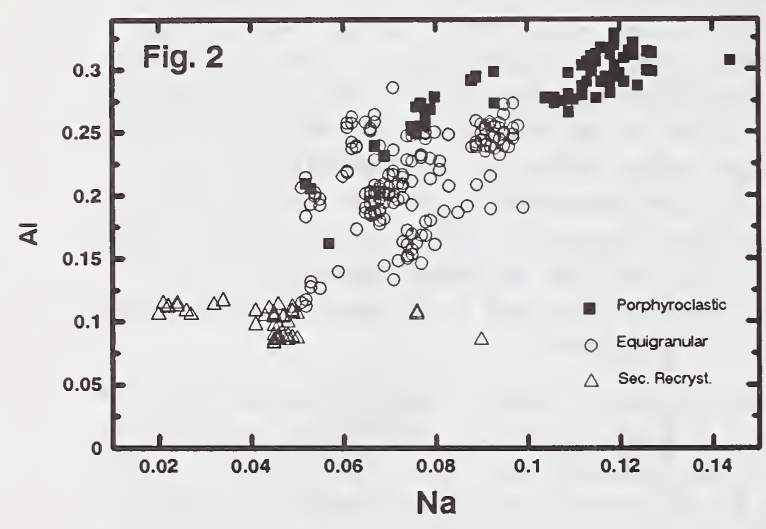

lineation is characteristic. The textures show signatures of secondary recrystal1ization. Based upon the lineation of the mica within these xenoliths, it would appear that the phlogopite predates the deformation event.

3) Olivine Hornblendite - The original olivine is largely replaced by amphibole which now constitutes more than $70 \%$ of the xenolith. Triple junctions, slight deformation, and twinning of the remaining olivine suggest an equigranular texture for the pre-alteration xenolith.

Cr-diopside-rich veinlets $(2-7 \mathrm{~mm})$ within the lherzolites and wehrlite have undergone the same overall deformation as the host xenoliths. It is obvious that the emplacement of this veinlet preceded the deformational event.

Mineral Chemistry - We have attempted to correlate mineral compositions with texture since it appears that the textures are representative of particular petrogenetic conditions. The ranges of mineral compositions of the spinel lherzolites and harzburgites are similar to many other occurrences (e.g., Basaltic Volcanism Vol., 1981; Nixon, 1987). Olivine and orthopyroxene have Mg 非 in the range of $0.87-0.91$ and $0.88-0.91$, respectively. The compositions of these phases are independent of textural type except for a small increase in $\mathrm{Al}_{2} \mathrm{O}_{3}$ in the orthopyroxene from porphyroclastic xenoliths. Clinopyroxene and spinel compositions vary with texture. In porphyroclastic and transitional xenoliths, clinopyroxenes are enriched in $\mathrm{Al}$ and $\mathrm{Na}$ compared to equigranular xenoliths (Fig. 2). The variation in Mg非 of the clinopyroxene is directly correlated with those of olivine and orthopyroxene. The spinels in porphyroclastic xenoliths are high in $\mathrm{Al}_{2} \mathrm{O}_{3}$ and have low $\mathrm{Fe}$ 作 values $\left[\mathrm{Fe}^{2+} /\right.$ $\left.\left(\mathrm{Fe}^{2+}+\mathrm{Mg}\right)\right](\mathrm{Fig} \cdot 3)$. 
Recrystallized xenoliths have distinctive compositions of clinopyroxene and spinel. Compared to compositions in other textures and as shown in Fig. 2, clinopyroxenes are low in $\mathrm{Al}_{2} \mathrm{O}_{3}, \mathrm{Na}_{2} \mathrm{O}$, and $\mathrm{FeO}$ and $\mathrm{high}$ in $\mathrm{SiO}_{2}$ and $\mathrm{Mg}$ 非 (0.91-0.93). As shown in Fig. $3,{ }^{3}$ spinels have the highest $\mathrm{Cr}$. $[\mathrm{Cr} /(\mathrm{Cr}+\overrightarrow{\mathrm{Al}})]$,

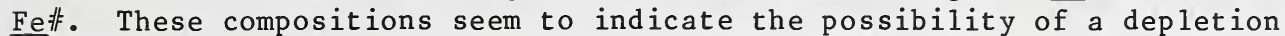
process having acted upon these mantle samples. The olivine of the highly metasomatized olivine hornblendite is characterized by enriched compositions of $\mathrm{Fe}$ and $\mathrm{Mn}$; the orthopyroxene is enriched in $\mathrm{Fe}, \mathrm{Mn}$, and $\mathrm{Ca}$. The spinel is depleted in $\mathrm{Mg}$ and $\mathrm{Al}$ (Fig. 3), which may be related to the formation of hornblende. The amphibole which occurs in all these xenoliths is $\mathrm{Ti}-$ and Cr-rich pargasitic, with higher $\mathrm{Al}_{2} \mathrm{O}_{3}$ than similar xenoliths from other world-wide localities. It is typically associated with remobilized spinel. Indeed, the interstitial setting of amphibole as a replacement phase and unstrained habit indicate formation after the deformation of the xenoliths.

In the recrystallized xenoliths, phlogopites occur with high contents of $\mathrm{TiO}_{2}(1.2-2.6 \%), \mathrm{Cr}_{2} \mathrm{O}_{3}(1.3-2.3 \%)$, and $\mathrm{Na}_{2} \mathrm{O}(0.7-1.1 \%)$. This chemistry is typical for secondary phlogopites of the upper mant le (Delaney et al.,

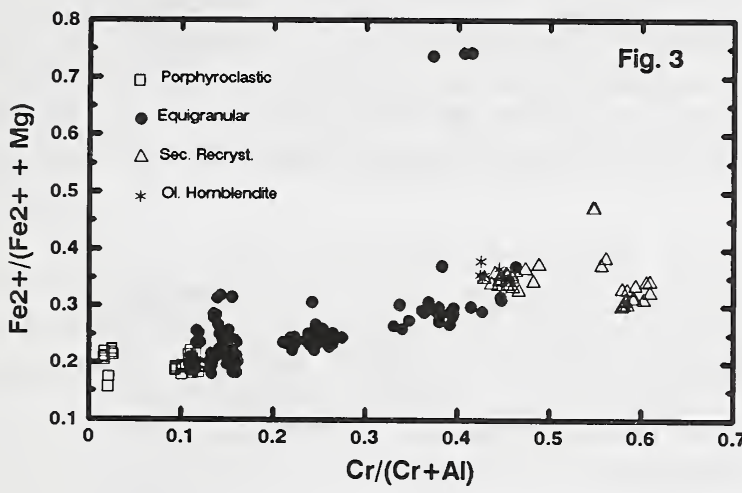
1980). The high $\mathrm{Mg}$. $(0.91)$ is in accordance with those of the other silicates, implying equilibration within the xenoliths. However, extremely high fluorine contents, up to $3.5 \%$, are uncommon in phlogopites in ultramafic xenoliths from the alkali basaltic series.

DISCUSSION: The textures of the xenoliths and mineral chemistry can be integrated into an overall scenario of mantle events within 7 the NGR portion of the CarpathianPannonian area of eastern Europe. These stages are depicted schematically in Figure 4 and are discussed below in chronologic order: 1) 1st Metasomatism; 2) Diapirism and Deformation; 3) 2nd Metasomatism; and 4) Entrainment and Volcanic Activity.

Stage 1. Ist Metasomatism Within the xenoliths, it would appear that there was an ancient metasomatism which resulted in the local formation of phlogopite. The upward migrating, metasomatizing fluids was rich in water, but also contained appreciable fluorine and potassium, as evidenced by the high Fluorine contents of the phlogopite. Although no garnet was found in these xenoliths, we cannot exclude that garnet was not completely replaced by this hydrous alteration. The phlogopite is distinctly lineated, indicating its formation before the deformation event.

Stage 2. Diapirism \& DeforFigure 4 M.y. mation All of the xenoliths

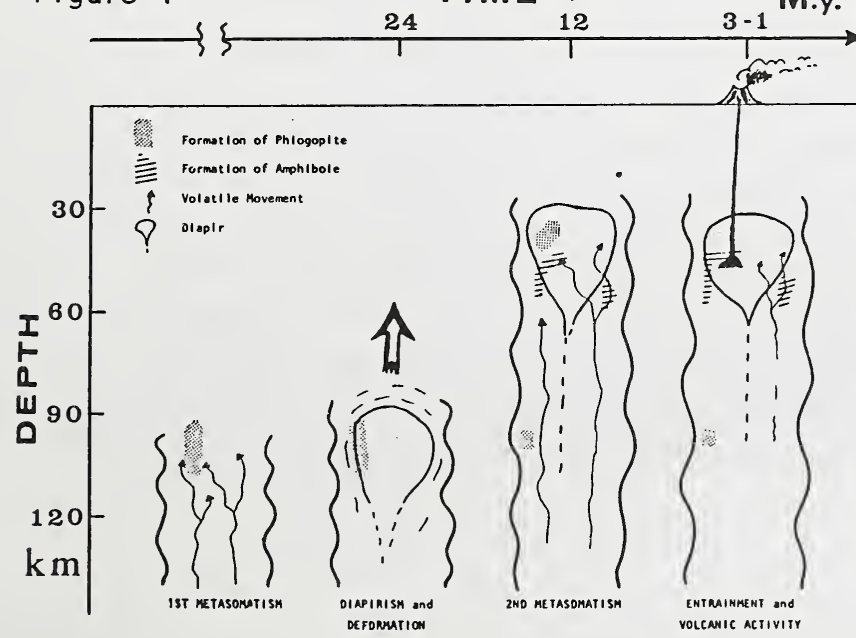
display evidence for strong deformational event. The most intense deformation, as revealed from the xenolith textures, was in the Southeast region of the NGR. The textures are mostly porphyroclastic to the Northeast \& progress to equigranular, to transitional and to secondary recrystallized as the region of most intense deformation is approached. We postulate that this deformation was associated with deep-seated diapiric movement, which began after the 
termination of subduction in the Carpathian belt at about 24 M.a. (Stegena et al., 1975). This diapiric upwelling continued until about $12 \mathrm{M} . \mathrm{a}$. when it reached its highest position at about $30 \mathrm{~km}$ depth. This is based upon heat-flow calculations and estima tion of the amount of crustal thinning (Dovenyi \& Horvath, 1988).

Stage 3. 2nd Metasomatism Possibly associated with or as, a direct consequence of the asthenospheric upwelling, another period of metasomatism affected the xenoliths. This is evidenced by the pervasive presence of undeformed amphibole superimposed upon the deformed texture of the mantle xenoliths. The presence of this pargasitic hornblende limits the depth of this metasomatism to less than about $70 \mathrm{~km}$.

Stage 4. Entrainment and Volcanic Activity Alkaline basaltic volcanism occurred within the last few million years. This entrained the mantle xenoliths and brought them to the surface. Geothermobarometric estimates of the xenoliths show last equilibration at $950-110^{\circ} \mathrm{C}$ and $8-18 \mathrm{kbars}$. These conditions correspond to the depth of entrainment at 27-60 km. Interaction with the basaltic melt resulted in breakdown of some of the amphibole, as well as small amounts of spinel and clinopyroxene. A new selvage of phases is present in place of these decomposed minerals and consists of secondary clinopyroxene, spinel, feldspar, phlogopite, amphibole, olivine, and glass. The presence of enriched contents of $\mathrm{K}$ and $\mathrm{Ti}$ in some of the product crystals indicate that their formation was the result of metasomatic fluid from the basaltic melt.

REFERENCES: Adam (1982) Geosci. Mining Bul1. Hungarian Acad. Sci. 15, 221-236; Balogh et al. (1986) Acta Miner.-Petro. Szeged 28, 75-93; Basaltic Volcanism Study Project (1981) p. 282-310. Pergamon; Delaney et a1. (1986) Geochim. Cosmochim. Acta 44, 857-872; Dovenyi \& Horvath (1988) AAGP Mem. 45. 195-235; Mercier \& Nicolas (1975) Jour. Petrol. 16, 454-487; Nixon (1987) Wiley \& Sons, $844 \mathrm{p}$; Stegena et a1. (1975) Tectonophysics 26, 71-90;

Wilshire \& Shervais (1975) Phys. Chem. Earth 9, 257-272. 